\title{
The McQueeney Municipal Utility District Project: An Archaeological Reconnaissance
}

T. C. Kelly

Thomas R. Hester

Center for Archaeological Research

Follow this and additional works at: https://scholarworks.sfasu.edu/ita

Part of the American Material Culture Commons, Archaeological Anthropology Commons, Environmental Studies Commons, Other American Studies Commons, Other Arts and Humanities Commons, Other History of Art, Architecture, and Archaeology Commons, and the United States History Commons

Tell us how this article helped you.

This Article is brought to you for free and open access by the Center for Regional Heritage Research at SFA ScholarWorks. It has been accepted for inclusion in Index of Texas Archaeology: Open Access Gray Literature from the Lone Star State by an authorized editor of SFA ScholarWorks. For more information, please contact cdsscholarworks@sfasu.edu. 


\section{The McQueeney Municipal Utility District Project: An Archaeological}

Reconnaissance

\section{Creative Commons License}

\section{(c) (1) (8)}

This work is licensed under a Creative Commons Attribution-NonCommercial 4.0 International License 


\title{
REF
}

\section{MCQUIEENEY MUNICIPAT UTITITY DISTIRICT IPROJIECT: AN ARCHAEOLOGICAL RECONNAISSANCE}

\author{
T. C. Kelly \\ and
}

Thomas R. Hester

CENTER FOR ARCHAEOLOGICAL RESEARCH

THE UNIVERSITY OF TEXAS AT SAN ANTONIO

ARCHAEOLOGICAL SURVEY REPORT, NO. 19 
THE MGQUEENEY MUNICIPAL UTILITY DISTRICT PROJECT:

AN ARCHAEOLOGICAL RECONNAISSANCE

T. C. Kel1y

and

Thomas R. Hester

Center for Archaeological Research

The University of Texas at San Antonio

Archaeological Survey Report, No. 19

1976 
TABLE OF CONTENTS

Page

Introduction

1

Previous Archaeological Research 1

The Survey

Archaeological Sites 4

Summary and Recommendations 14

$\begin{array}{ll}\text { References Cited } & 18\end{array}$ 


\section{FIGURES}

Page

1. Locations of Archaeological Sites in the 3 Vicinity of the McQueeney Municipal Utility District.

2. Archaeological Sites in the Area of the McQueeney Utility District.

3. Artifacts from 41 GU 12.

8

4. Artifacts from 41 GU 13.

5. Artifacts from 41 GU 14 . 12

6. Artifacts from 41 GU 14 . 13

7. Artifacts from 41 GU 15. 15 


\section{INTRODUCTION}

During late March, 1976, the Center for Archaeological Research, The University of Texas at San Antonio, conducted an archaeological reconnaissance in the vicinity of McQueeney, in Guadalupe County, Texas. This reconnaissance had been authorized by the McQueeney Municipal Utility District in connection with its plans for sewage 1 ines and waste treatment facilities in the McQueeney area. Survey work was facilitated through contacts with URS Forrest and cotton (project engineers) and with Mr. M. 0. Stautzenberger, president of the utility district. We are gratefut to $\mathrm{Mr}$. Stautzenberger for providing the field team with a 1:300 aerial photograph of the project locality, and for making the necessary entry arrangements with Tocal landowners.

\section{PREVIOUS ARCHAEOLOGICAL RESEARCH}

Guadalupe County has seen little archaeological activity on the part of professional archaeologists (Hester 1974). At the time this reconnaissance was initiated, only nine archaeological sites had been previously recorded with the Texas Archeological Research Laboratory at The University of Texas at Austin. Of these, most span the Archaic (ca. 6000 B.C. to ca. A.D. 1000) and Late Prehistoric (ca. A.D. 1000 to historic contact) time periods; three are 19th century pottery kiln sites. Three historic structures, the Holloman house, Los Nogales, and Sebastopol (Zorn House), have been submitted to the National Register of Historic Places. We could locate only three published references to Guadalupe County archaeology, and these deal only briefly with specific artifact forms recorded in the area (Patterson 1936, 1937a, 1937b).

Given the fact that a major drainage system, the Guadalupe River, passes through the middle of the county, and with sizable drainages like the San Marcos River and Cibolo Creek constituting the county's northeastern and southwestern boundaries, we can safely predict that bountiful archaeological resources will be found when systematic, scientific surveys are initiated in the area. Studies such as the recent Texas Family Land Heritage Registry indicate that a number of significant historic structures (dating between 1840-1875) exist in Guadalupe County (Harper 1974: 63-64).

\section{THE SURVEY}

The field work performed by the Center for Archaeological Research can be best described as a "cuitural resources reconnaissance" (General RuTes of Practice and Procedure 1976). The sewage treatment system of the MicQueeney Municipal Utility District is in the planning stage, and the district and its consulting engineers wished to ascertain the nature and extent of archaeological resources within the boundaries of the proposed project. The area covered by the reconnaissance is shown in Figure 1 . 
The investigations were under the generai supervision of Dr. Thomas R. Hester, Director of the Center. Field work was directed by T. C. Kelly, aided by E. T. Miller. C. D. Orchard of McQueeney shared his knowledge of the local archaeology with the field team, and we express our thanks to him for this assistance.

Much of the project area has already seen extensive modification in the form of housing, roads, borrow pits, recreational developments, etc., and these localities were only briefly examined. However, fields and undeveloped areas were more closely checked, with on-the-ground survey and limited testing conducted where possible.

As a result of the cultural resources reconnaissance, six prehistoric archaeological sites were located and documented. One structure of possible historic interest was also noted. One of the prehistoric sites, 41 GU 13, is of such significance that we intend to nominate it to the National Register of Historic Places.

A11 materials resulting from the survey (artifacts, field notes, photographs, site survey forms) are on file at the Center for Archaeological Research. Copies of the site survey forms have been filed with the Texas Archeological Research Laboratory in Austin. 
This page has been

redacted because it

contains restricted

information. 
ARCHAEOLOGICAL SITES

McQueeney \#1 (41 GU 10)

This site was reported to the field team by C. D. Orchard. It is located south of the intersection of County Road 352 with the Treasure Island access road, between sloughs east and west of the Treasure Island bridge (Figure 1). The east half of the site is on the property of Mrs. Lois Koehne, while the west half belongs to Mrs. Nerna Skidmore Eller. Mr. Orchard has a collection of large bifaces, choppers, and dart points (Gary-like, Pedernales, and Frio) from the site. Mrs. Koehne has a small collection of similar artifacts, and Mrs. Eller could not locate a collection of chert artifacts and pottery that she found when the access road was built. She also stated that numerous pieces of pottery were collected when her barbeque pit, located within two meters of the road, was buitt.

The survey team could find no surface evidence of an archaeological site on either property. Mrs. Eller gave permission for the excavation of a one-meter square test pit, placed alongside the barbeque pit. It was excavated in 20 centimeter levels to a depth of 80 centimeters.

No finished artifacts were found during the testing activities. However, 67 chert flakes were recovered. Flake categories and proveniences according to test pit levels are tabulated below:

41 GU 10: Test 1 level 1 level 2 level 3 level 4

$\begin{array}{lrrrr}\text { Primary flakes } & 1 & 3 & 1 & 0 \\ \text { Secondary flakes } & 1 & 3 & 1 & 0 \\ \text { Interior flakes } & 13 & 21 & 11 & 4 \\ \text { Lipped flakes } & \frac{0}{15} & \frac{3}{30} & \frac{2}{15} & \frac{1}{5} \\ \text { Total } & & & \end{array}$

Two bone fragments from level 2 were the only other materials found. The soil was a tan, sandy-clay soil, very homogenous in texture. The high incidence of interior flakes, compared to primary and secondary flakes suggests that final stages in the stone-knapping process were being carried out in the near vicinity. The frequency of lipped flakes indicates that bifacial reduction, perhaps dart point manufacture was one function of the site.

If sewage lines to Treasure Island area are placed along the access road, it is recommended that test pits be excavated along the selected route. Perhaps most of the site was destroyed during the construction of the access road. On the other hand, much of it may still lie buried in the area. Given the nature of the Orchard collection, Archaic occupations can be presumed for the site. Mrs. Ellers' recollections of the presence of ceramics in the site deposits indicate that late 
Figure 2. Archaeological sites in the Area of the Molueeney Utility District. a, view of site $41 \mathrm{GU}$ 13, looking north; $b$, view of site 41 GU 14, looking north. (Photographs by T. C. Kelly). 


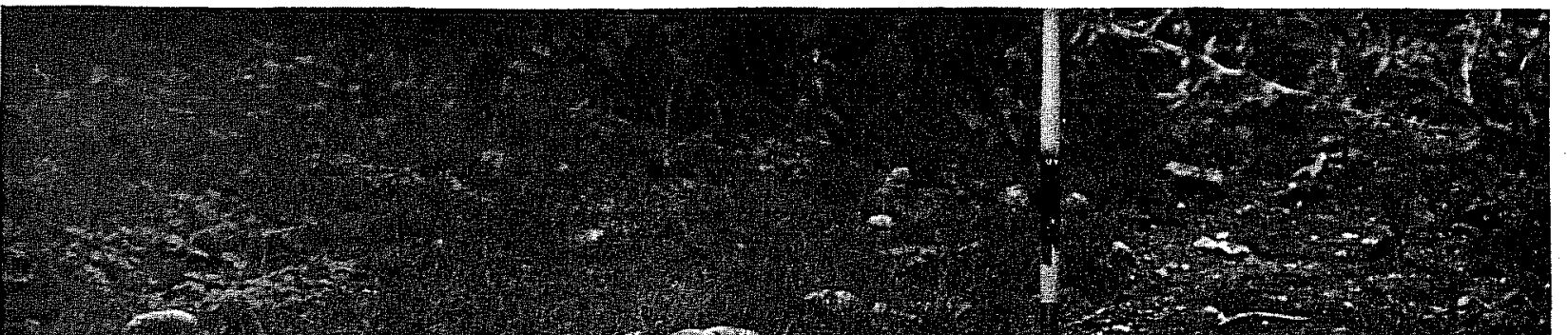

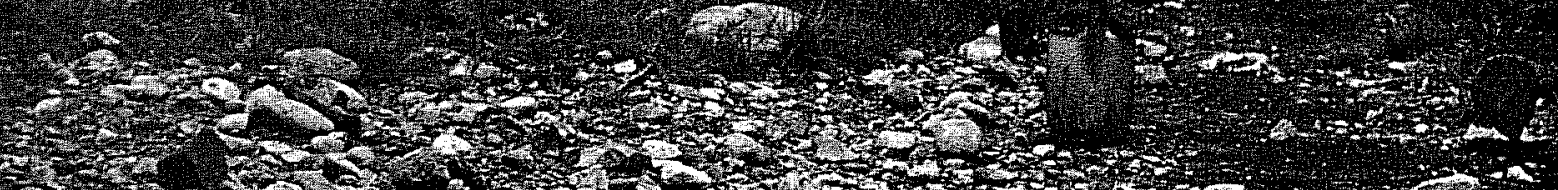

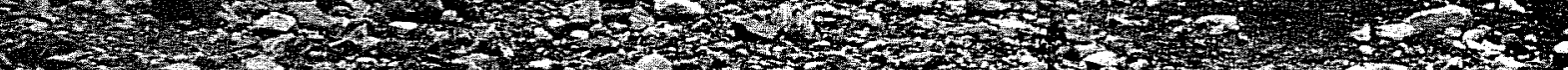

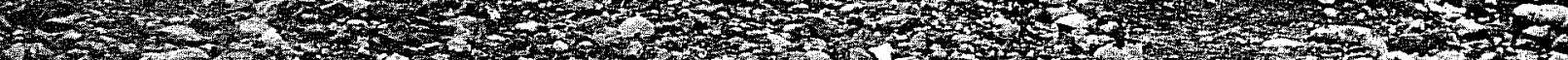

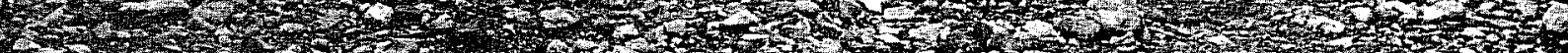

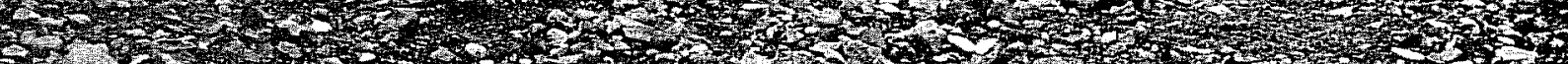

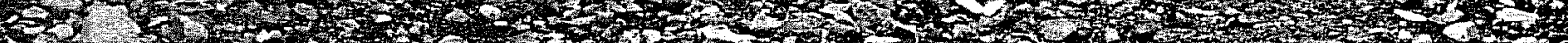

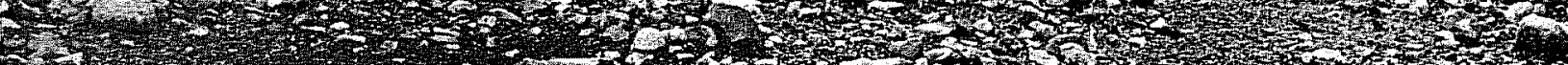

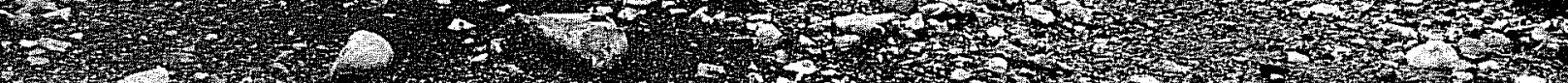

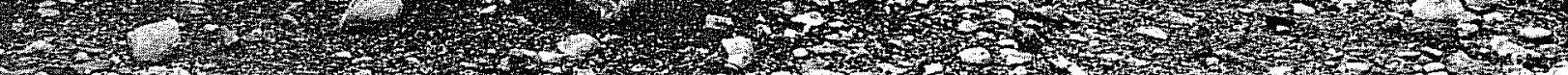

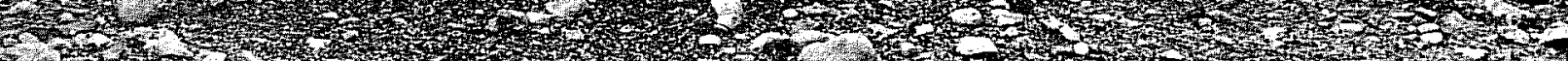

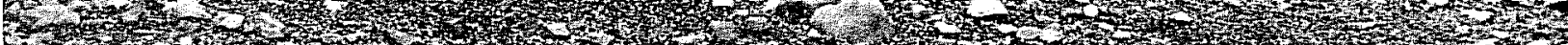

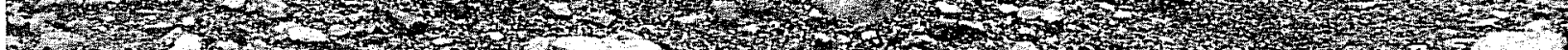

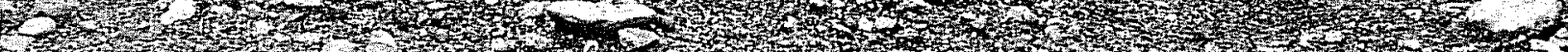

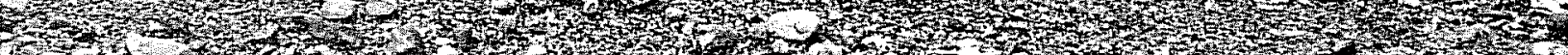

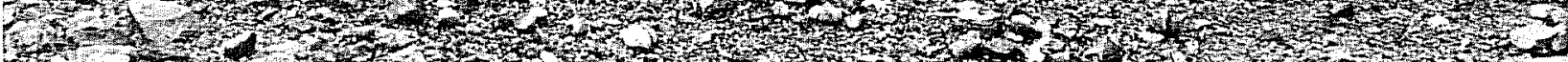

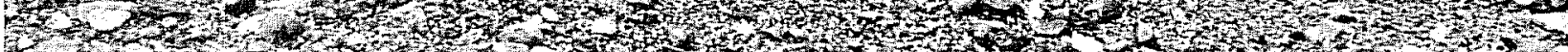

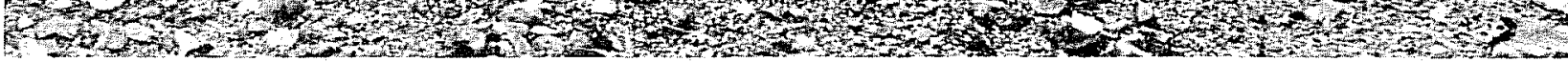

\section{a}

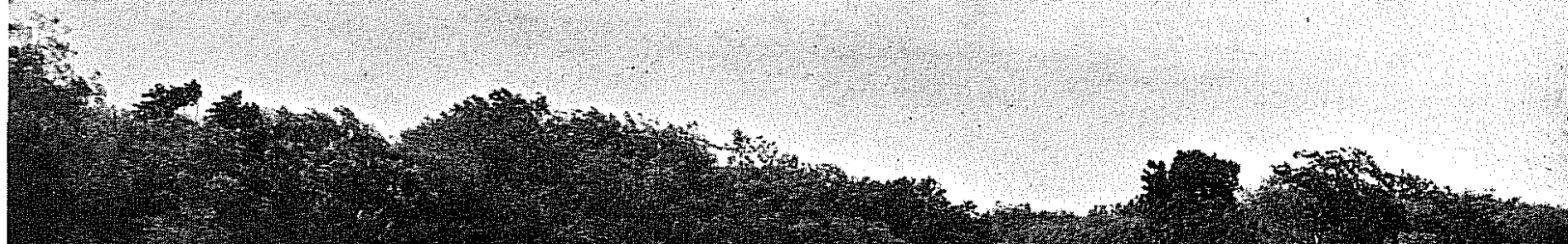

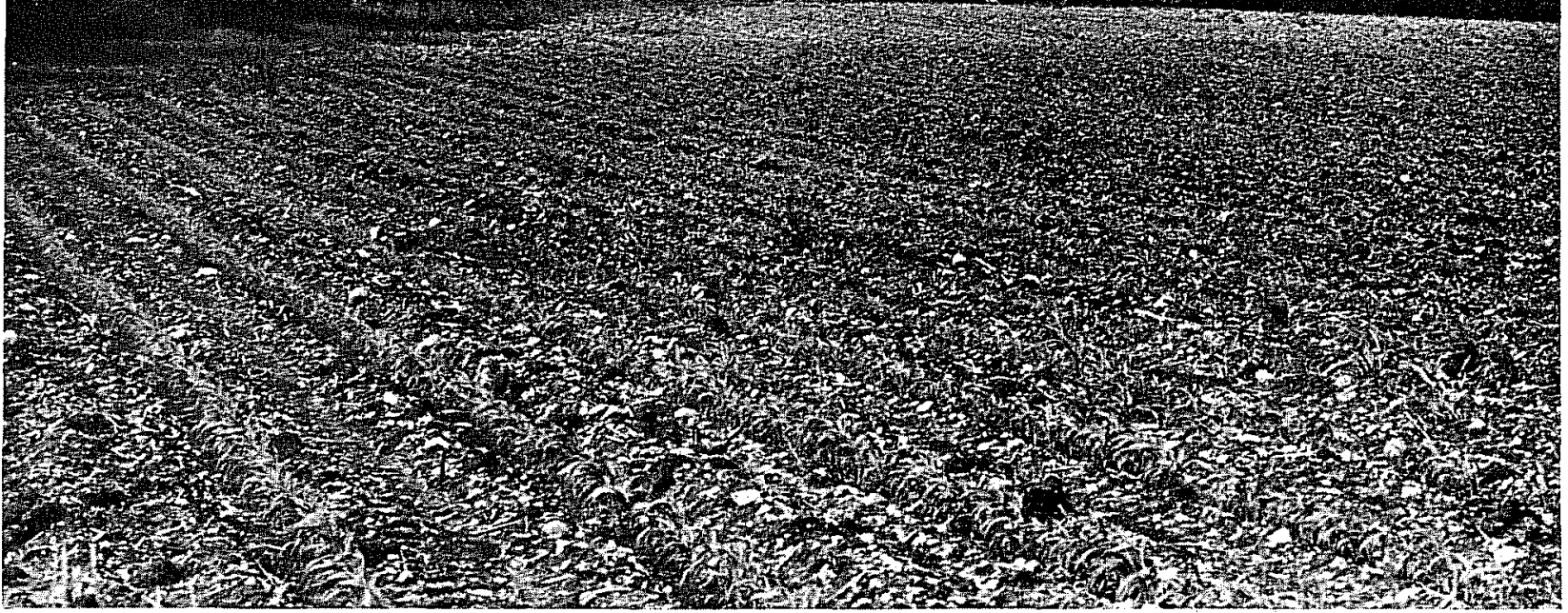


prehistoric components may be also expected.

McQueeney \#2 (41 GU 11)

Mr. Orchard identified this as a quarry/knapping site (Figure 1) from which he had collected debitage in 1930-31. Presently it is covered by several smal1 homesteads and entry permission could not be obtained. An outcrop of chert can be observed from the road.

The site has apparently been destroyed, and the proposed sewage lines could do no more damage than has already been done.

McQueeney \#3 (41 GU 12)

The site is located in a field owned by Mr. "Buzz" Mueler across FM Road 725 from the Ski Lodge (Figure 1). The site begins 300 feet southwest of a power line that crosses the field roughiy parallel to FM Road 725. The southern boundary is just short of the fence separating the field from an adjacent field containing a large earthen tank. Three gullies cut the site in this direction, and most archaeological materials were found in these shallow erosional cuts. Another guily drains the site to the west 650 feet south of an old farmhouse that might be of historic interest. The area closest to the power line is on the highest point - in the field and is not eroding. The exposed site is approximately 525 feet north-south by 780 feet east-west and roughly elliptical in shape. All drainage from the field empties into a creek 1000 feet to the southwest. The field is in cultivation. The soil is tan sandy clay with an area of much lighter soil near the oid farmhouse.

Chert debitage and artifacts cover the entire site area with fairly uniform distribution. The following small selective sample was obtained: Pedernales and Lange dart points; a Scallorn arrow point; large steep $7 y$ beveled and small end scrapers; a hammerstone of igneous rock; a crude, heavily battered core tool: a heavily patinated exhausted core; an ovate biface; four lipped flakes; and three weathered nodules of asphaltum (see Figure 3).

It appears that the site was occupied at least during the Middle and Late Archaic, and into Late Prehistoric times. There is considerable material still exposed at the site despite the fact that it is apparently known to local relic-collectors. It occupies what may have been a strategic position on the highest ground between the Guadalupe River to the east and Youngs Creek to the west. It is probabiy not threatened by the proposed sewage treatment system, but is in the process of being destroyed by plowing and erosion.

Should the site be examined by professional archaeologists in the future, we suggest that several test pits be dug to depths below the plow zone 


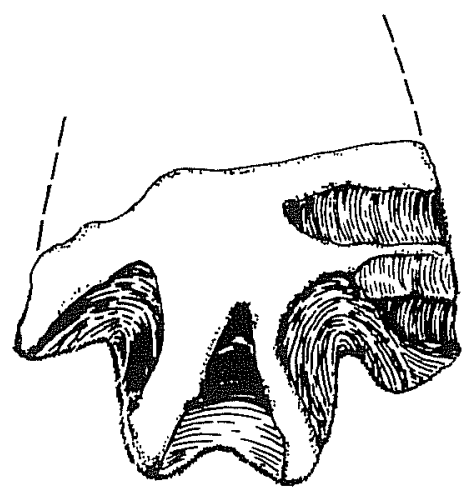

a

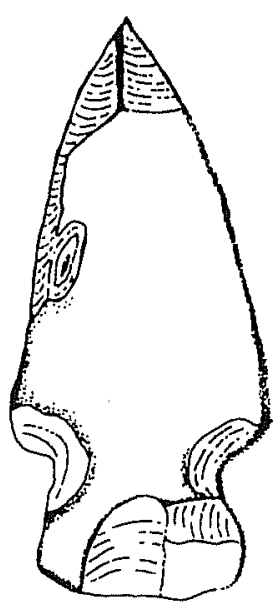

b
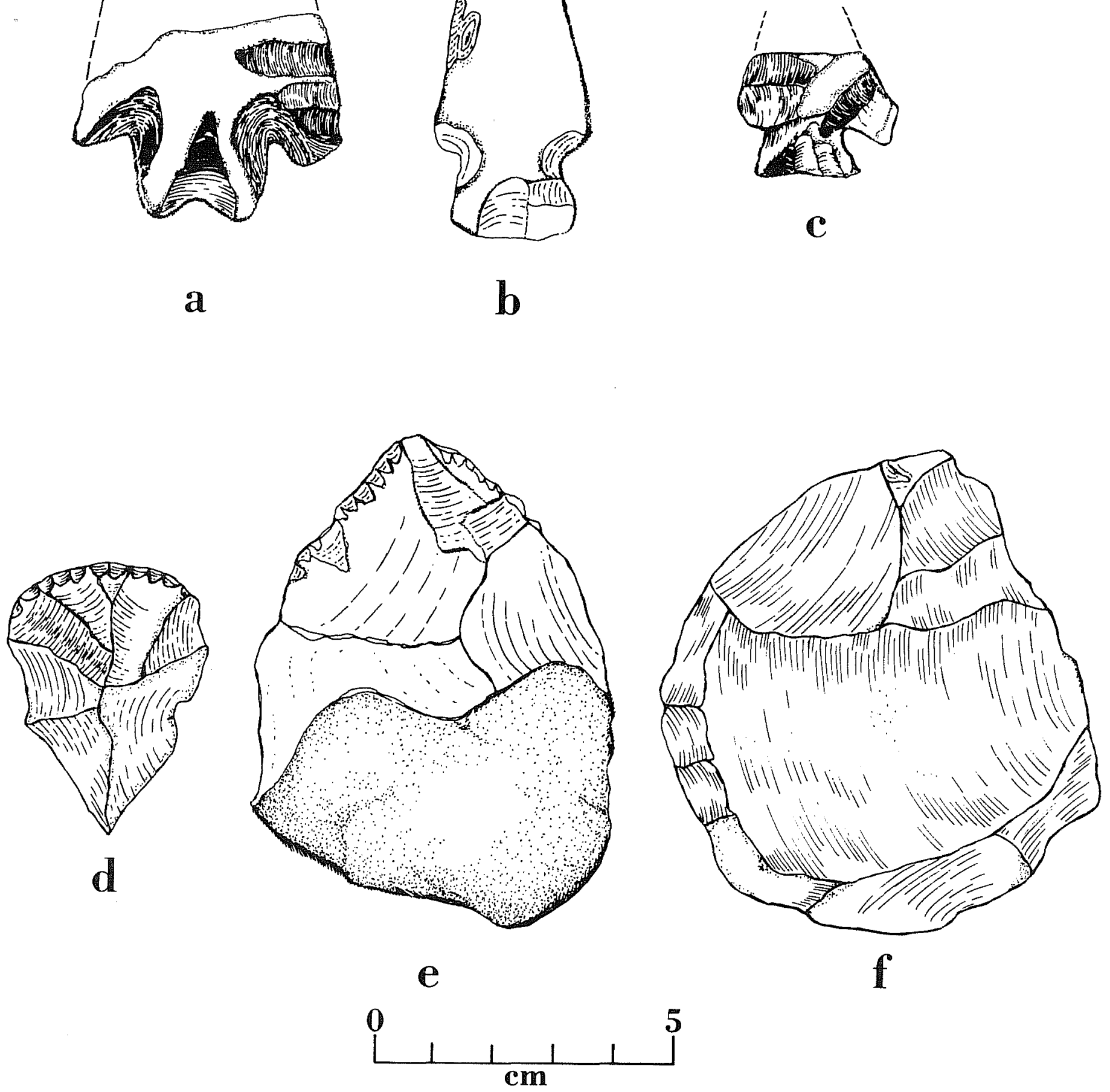

Figure 3. Artifacts from 41 GU 12. a-c, dart points; d, end scraper; e, core tool; $f$, core. 
in the relatively undisturbed highest area in this site. Such testing could reveal whether or not any intact deposits still remain.

McQueeney \#4 (41 GU 13)

The site is located at the north end of a long, high ridge overlooking and paralleling the east bank of the Guadalupe River, 4800 feet north of the Southern Pacific railroad (Figure 1). It is in a heavily wooded area at the north end of the property owned by Mrs. Martin Ebest. An old borrow pit on the east side of this wooded area is the only apparent disturbance in the vicinity. The site dimensions are 300 feet north-south by 100 feet east-west. There is possibly an accumulation of burned rock in the southern portion of the site, as well as an area of sandy alluvial clay to a depth of at least 45 centimeter, stained by the presence of charcoal throughout. The woods are fairly dense; the field team noted the occurrence of mesquite, persimmon, chinaberry, prickly pear, and several forms of cactus. An abundant source of chert cobbles is exposed in the plowed field to the south of the wooded area (see Figure $2, A$ ).

The site is centered around the 596 foot contour marker on the USGS McQueeney Quadrangle Map (7.5') and is 66 feet higher than the wide flat bench along the river below. A continuous trail of chert goes down the steep bank to the bench which must also conta in archaeological materials under a dense grass cover. This locality is the only undeveloped area observed by the field team in the vicinity of Lake McQueeney.

Chert debitage and artifacts are found all over the site. No effort was made to secure a surface sample as a.11 diagnostic artifacts have apparently been picked up by relic-collectors. In order to better evaluate the site and to determine the depth of possible occupation, a 50 centimeter square shovel test was dug near the north end of the site in two arbitrary 20 centimeter levels. A tabulation of materials recovered from this test pit follows (see also Figure 4):

Tevel 1 Tevel 2

Primary flakes

Secondary flakes

Interior flakes

Lipped flakes

Burned flakes

Total flakes

\begin{tabular}{rr}
42 & 11 \\
72 & 7 \\
192 & 47 \\
15 & 6 \\
21 & 5 \\
\hline 342 & 76
\end{tabular}

Perdiz point

Unidentified points

1 


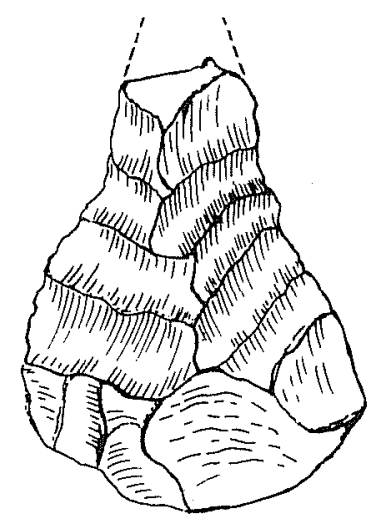

a
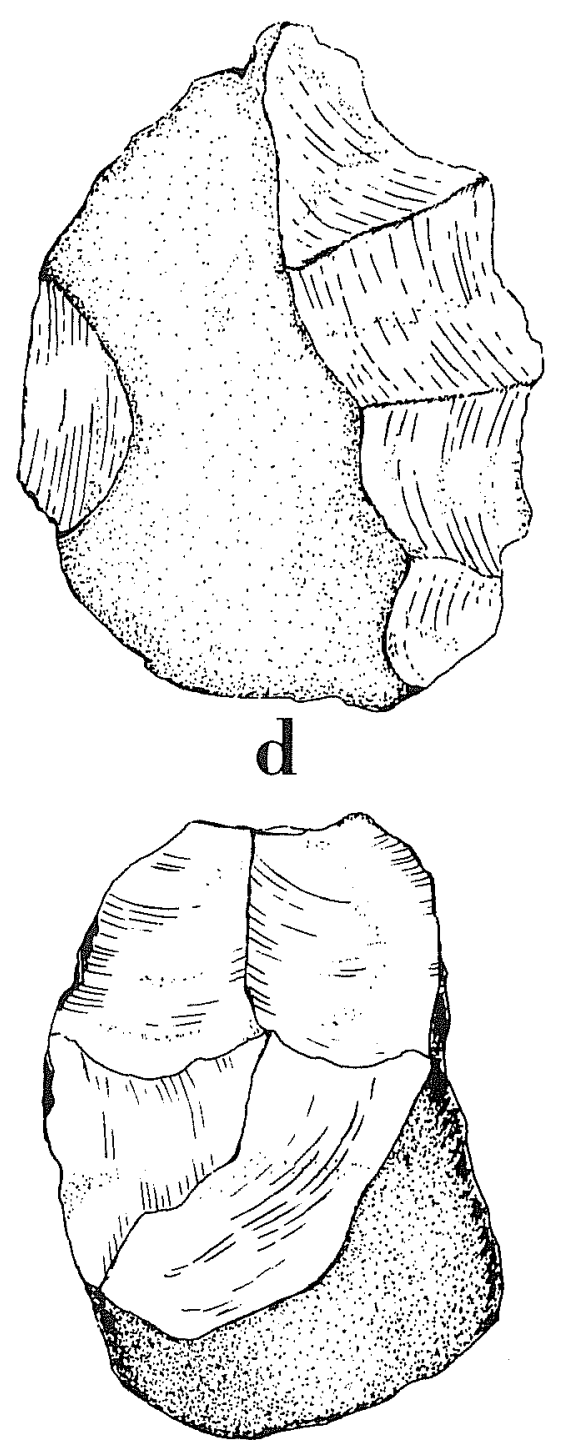

$\mathbb{e}$
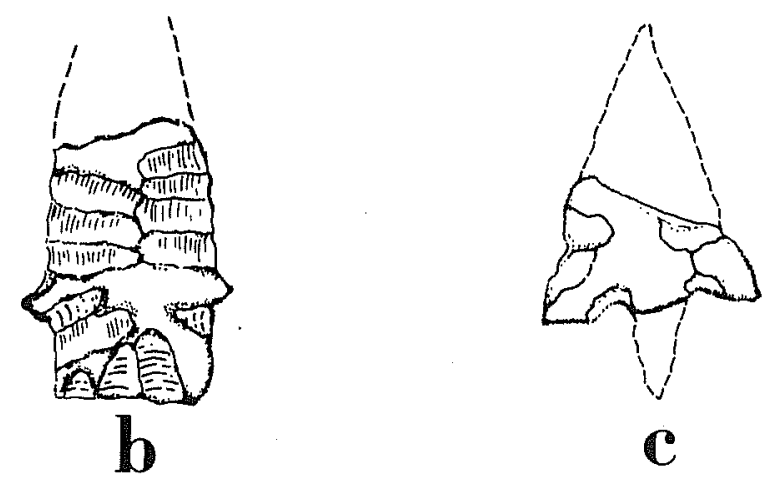

$\mathbb{C}$
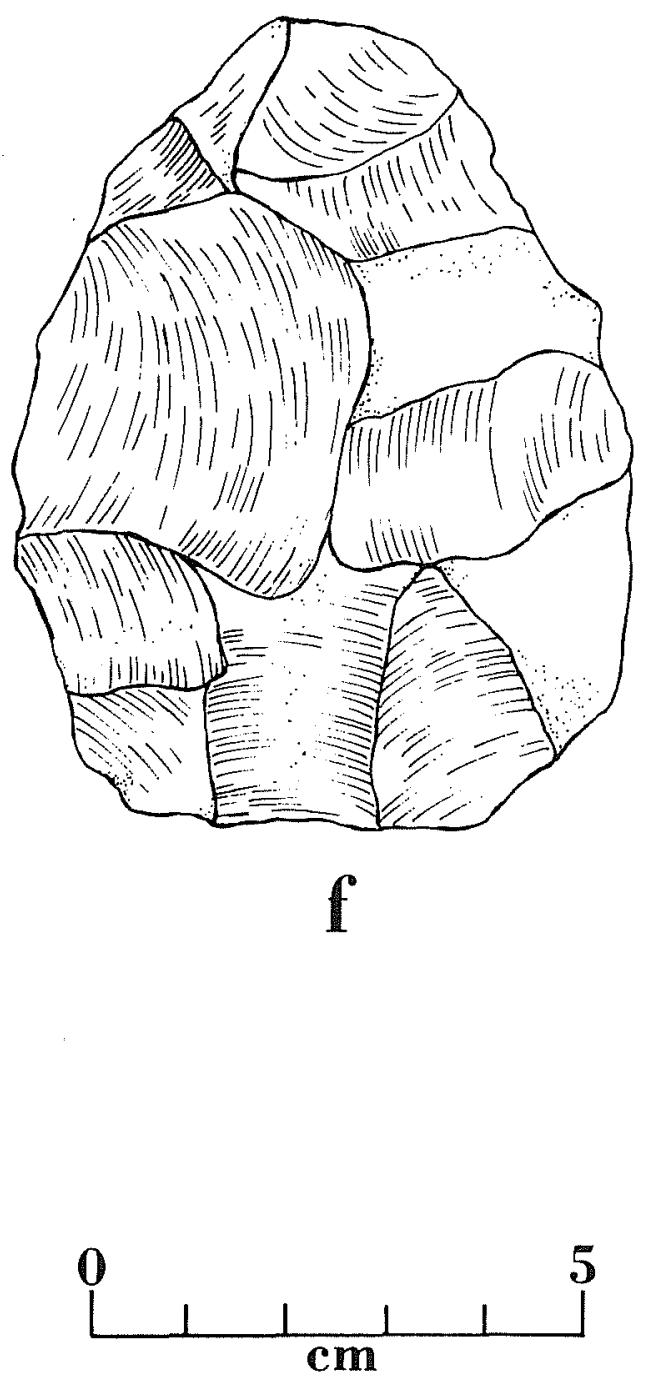

Figure 4. Artifacts from 41 GU 13. a, b, dart points; c, arrow point; d, denticulate scraper; e, modified pebble (probable core); f, crude biface (probable core). a-c, $d$, are from the test pit; other specimens, surface. 
(continued)

Perforator

Mussel shell fragments

Bone fragments

Denticulate scraper

Large core

$\begin{array}{ll}1 & \\ 0 & 4 \\ 0 & 7 \\ & 1\end{array}$

We suspect that the site saw rather intensive occupation during the Archaic and Late Prehistoric periods. This is the most outstanding site found during the survey and is in an excellent state of preservation. However, it lies in a choice area for future development and is thus not likely to survive much longer. It is not yet certain as to whether the proposed sewage lines will pass along the top of the bluff, or in the bench and floodpla in area below. In either case, further exploration is recommended so that valuable archaeological resources will not be destroyed.

Site 41 GU 13 is of sufficient importance to warrant its nomination to the National Register of Historic Places.

McQueeney \#5 (41 GU 14)

The site covers an area 750 feet north-south by 60 feet east-west, along the top of a high ridge that parallels the Guadalupe River. The ridge begins at the gate to the Ebest home, 3000 feet north of Highway 78 at the eastern city 7 imits of the town of McQueeney. There is an old abandoned farmhouse on top of a ridge 600 feet northeast of the gate and the site begins in the plowed field 300 feet northwest of it. The site continues almost to a cross fence between the field and a wooded area to the north (in which $41 \mathrm{GU} 13$ is located). There are hugh quanitites of chert cobbles and nodules in the plowed field and it is obviously the quarry site for both this site and 41 GU 14 (Figure $2, b$ ).

Quantities of debitage and artifacts are exposed in the furrows of the field and on the surface of an undisturbed area along the fence 1 ine. Again, the likelihood that collectors have visited the site is suggested by the absence of diagnostic artifacts such as dart points. The few artifacts collected are not diagnostic of any particular period. The kinds of chipped stone materials observed at the site include: a biface preform, and an exhausted core (the latter had seen possible secondary use as a scraping implement). Several artifacts from 41 GU 14 are shown in Figures 5 and 6.

It does not appear that the site will be affected by the proposed sewage treatment facilities. Should any modification of the site area be contemplated, it is urged that test pits be excavated in the undisturbed area in order to ga in a better assessment of the site. 


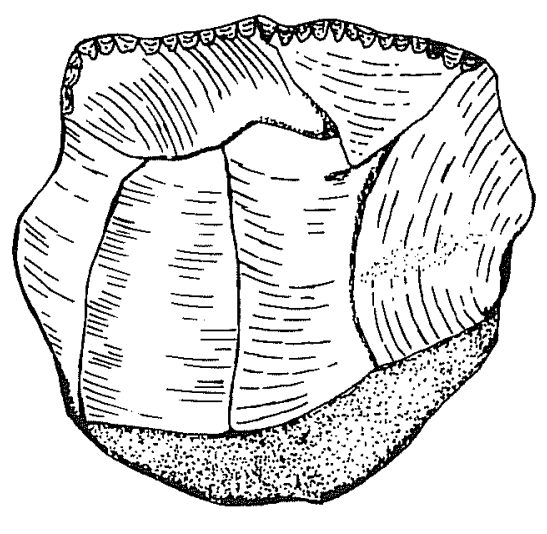

a

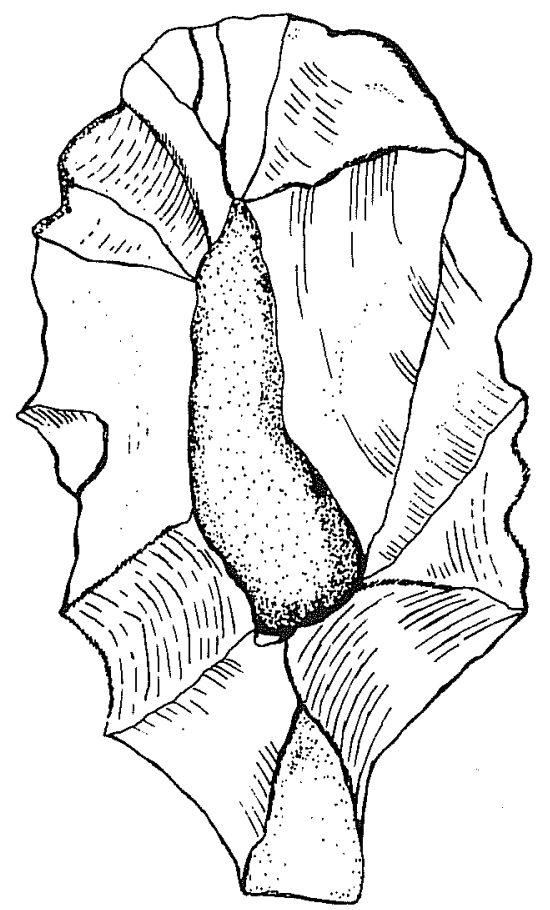

C
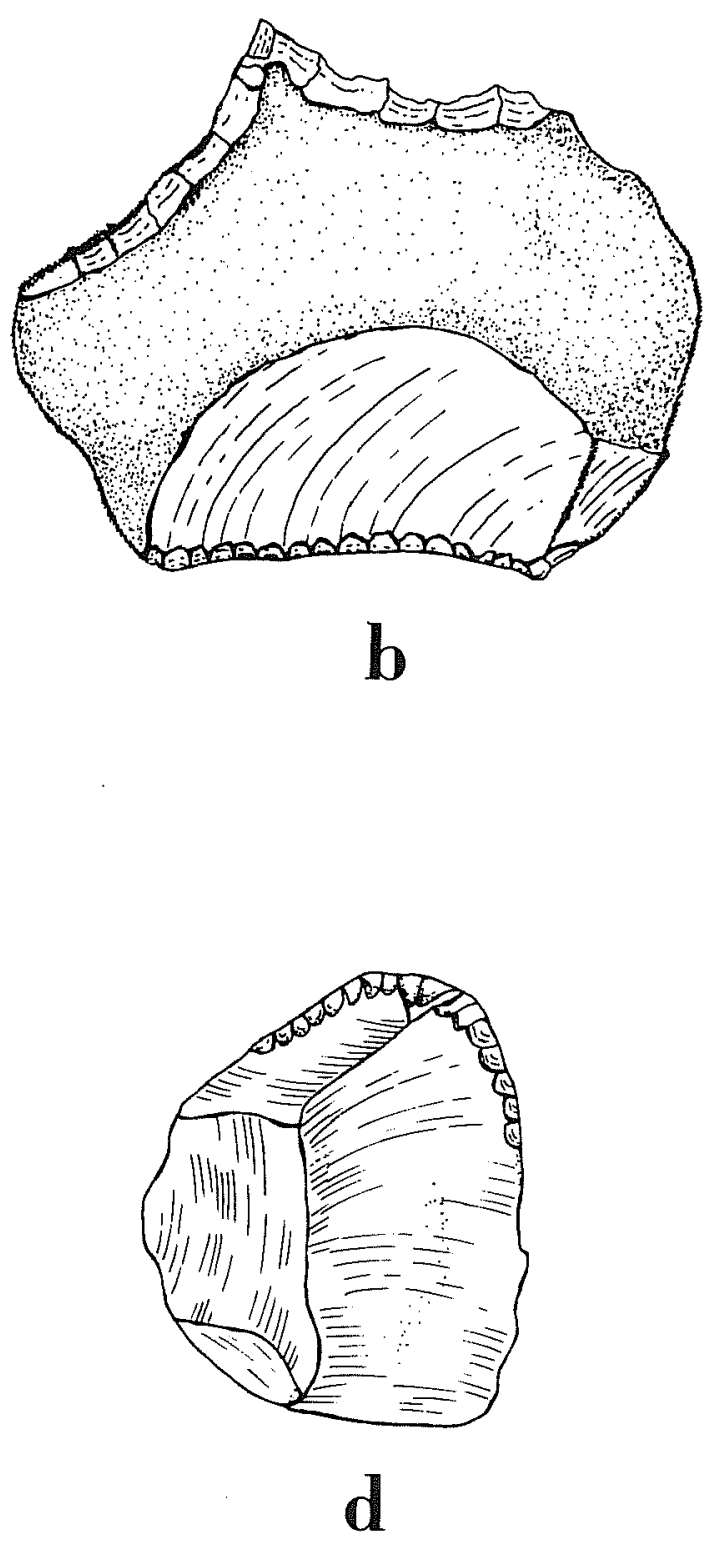

Figure 5. Artifacts from 41 GU 14. a-d, unifaces. a, d, apparent scrapers made on exhausted cores; b, possible graver; $c$, possible end scraper. 

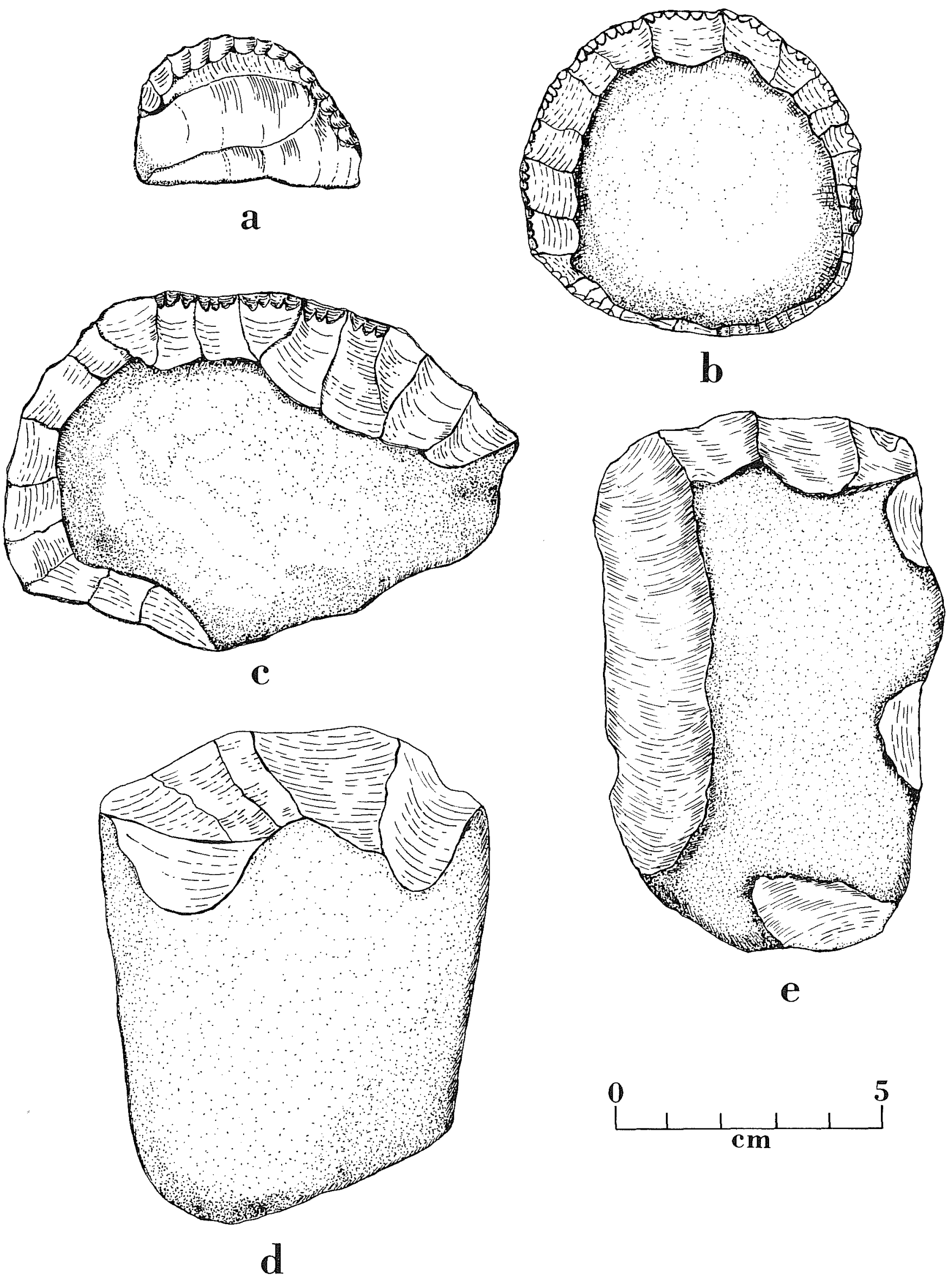

Figure 6. Artifacts from 41 GU 14. a-c, unifaces (probable scrapers); d, biface cobble chopper; e, quarry blank. 
McQueeney \#6 (41 GU 15)

The site is on the north end of the long ridge 4800 feet north of 41 GU 13 (Figure 1). An old gravel pit with a flowing spring is just north of the site. The area below the ridge toward the Guadalupe River is developed and a cultivated field marks the east boundary of the site. The top of the ridge is fairly flat and slopes gently to the Guadalupe River floodpla in below. It is covered with grass and mesquite trees. Exposed on the site surface is lithic scatter consisting of flakes, cores, and tools (Figure 7). Only two dart point fragments were found, again suggesting that the area is frequented by relic-collectors.

The site is 350 feet long (north-south) and 200 feet wide (east-west), and is being eroded. No major concentrations of occupational debris were found.

Artifacts collected were a bifacial tool possibly used as a chopper, a thick uniface (scraper), a small biface, and two Archaic dart point fragments (see Figure 7 ).

No further work is recommended at the site.

\section{SUMMARY AND RECOMMENDATIONS}

A preliminary archaeological reconnaissance of areas slated for modification by a proposed sewage treatment system in the vicinity of McQueeney, Texas, has led to the documentation of six archaeological sites. The reconnaissance revealed that much of the contemplated project area has aTready been seriousily disturbed--in terms of the potential archaeological resources--by modern development, including houses, roads, a railroad, a dam, and borrow pits. However, sites were found or reported in most parts of the project locality. During this preliminary reconnaissance, the field team was unable, due to a Tack of time and problems with entry permits, to examine less developed areas on the east side of the Guadalupe River. When other undeveloped areas were checked (such as the vicinity of 41 GU 13), archaeological resources were found; thus, we suspect that when these other areas are examined, sites will be found.

The six sites documented in this reconnaissance include major occupation sites (41 GU 12, 41 GU 13), sma 11, probably short-term or functionspecific sites ( 41 GU 14, 41 GU 15), a site related to stoneworking (41 GU 11), and one site whose function or character we cannot yet assess ( 41 GU 10).

Diagnostic artifacts from these sites suggest occupations by hunting and gathering populations during the Archaic and Late Prehistoric eras. There has apparently been intensive relic-collecting at many of the sites: diagnostic tools have been removed by these activities, making surface assessments even more difficult. Of particular note was the presence of several pieces of asphaltum at site $41 \mathrm{GU} 12$. Such 


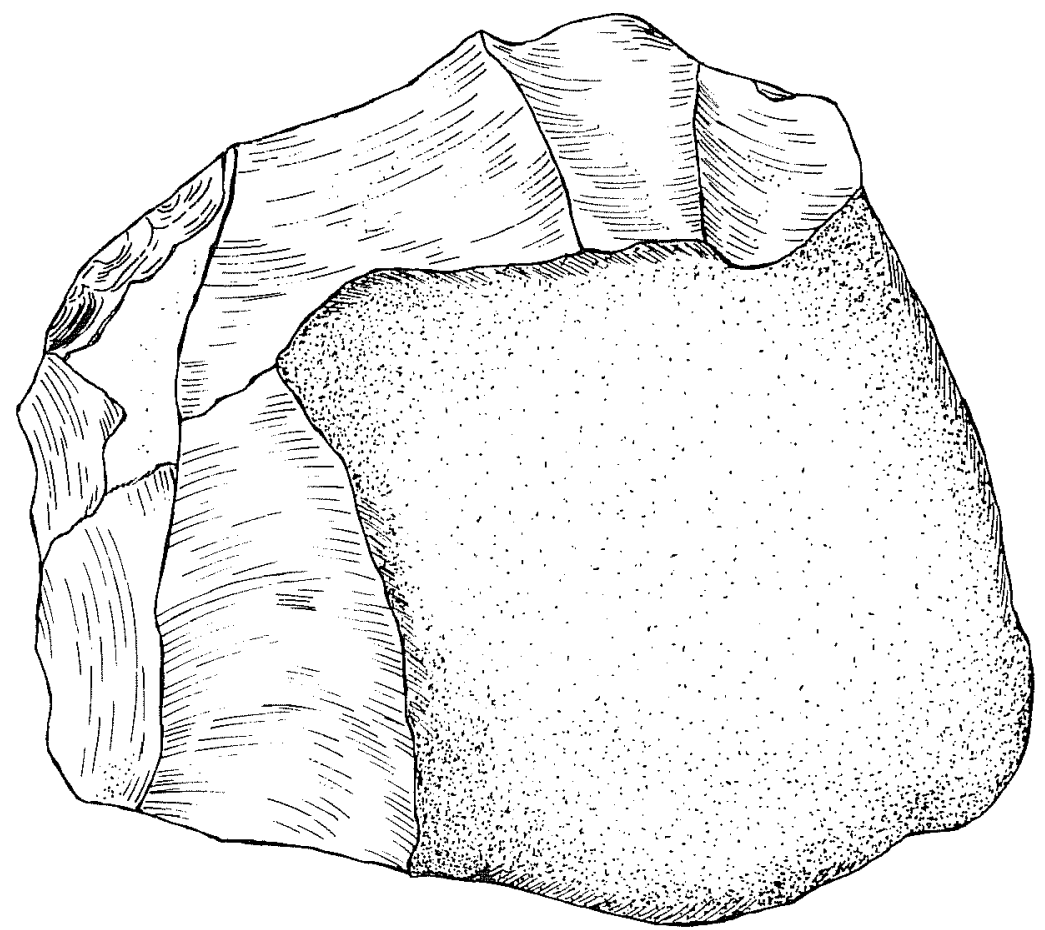

a
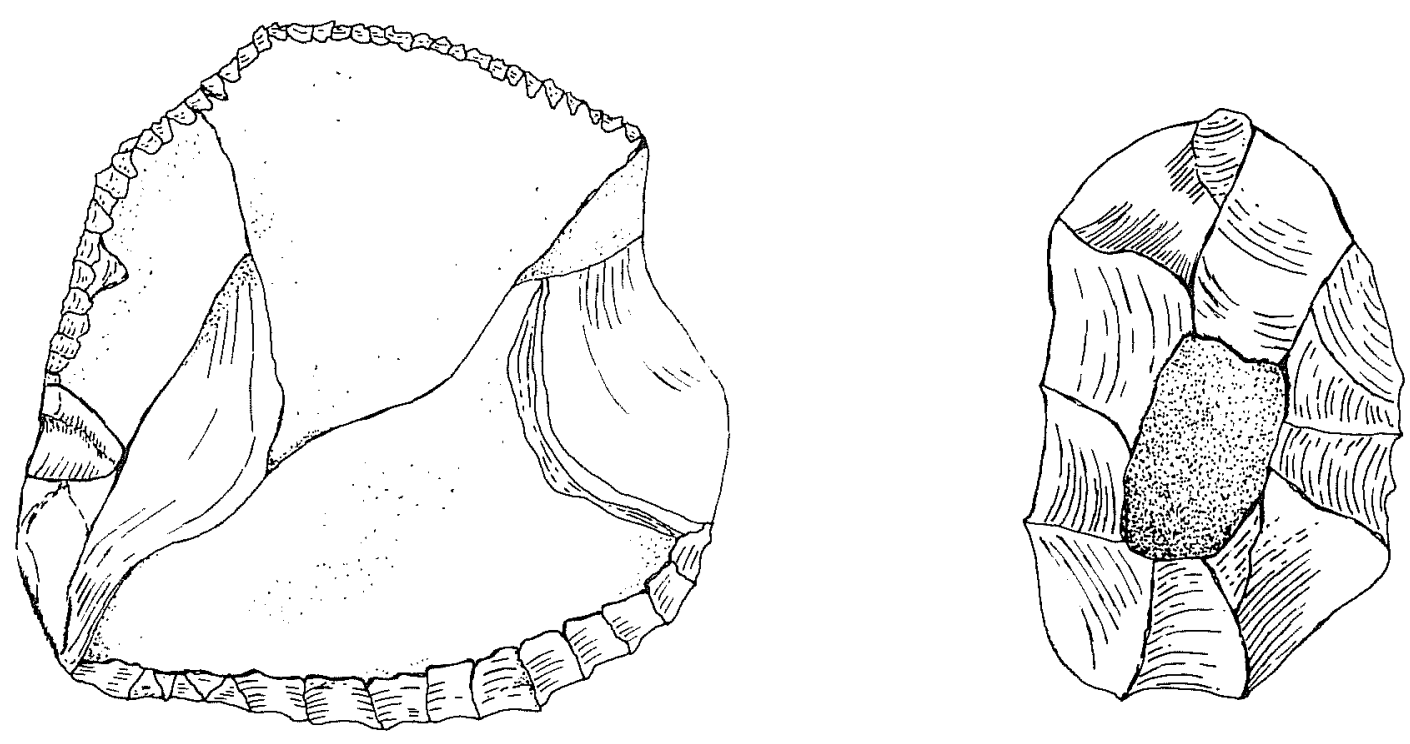

b

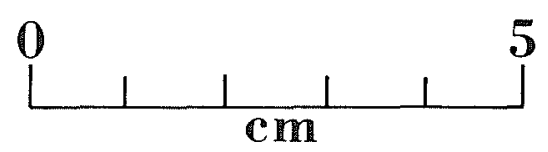

C

5. a, crude biface (possibly a chopper); b, Figure 7 . Artifacts from 41 GU 15 . a, crude biface (possibly
thick uniface (scraper); c, sma 11 biface (possible preform). 
material washes ashore along portions of the Texas coast, and was heavily utilized by coastal aboriginal groups. Its occurrence here suggests possible contacts with coastal populations.

The reconnaissance has demonstrated that archaeological sites still exist within the boundaries of the McQueeney Municipal Utility District. At present rates of development in the Lake Mcqueeney area, few sites can be expected to survive very long. Other sites are undoubtediy present within the project area and could be identified by an intensive survey. Such a survey should be done soon, as it is our understanding that the URS Forrest and Cotton plan for sewage lines and wastewater treatment is still in the conceptual stage. Protection of archaeological resources may in some cases be possible by making minor changes in the developing plans for the sewage treatment system. This would be, it seems to us, the least expensive and most desirable way to protect and preserve archaeological sites.

The following specific recommendations are made for the six sites so far identified, and for future intensive survey:

McQueeney \#1 (41 GU 10). Determine if proposed use of access road for placement of sewage lines to Treasure Island is necessary. If aiternate route is not feasible, test pits should be excavated along selected route between the Treasure Island bridge and County Road 352.

McQueeney \#2 (41 GU 11). No further action is recommended.

McQueeney \#3 (41 GU 12). This potentially valuable site has a Tready been considerably damaged by erosion and plowing. The proposed project, as is presently outlined, wil? have only minimal impact on the site. Intensive surface survey and test pitting should be done prior to any modification of the site area resulting from the project.

McQueeney \#4 (4T GU 13). This is the most significant site Tocated in the survey and is practically undisturbed. It contains an abundance of archaeological remains, charcoal, and bone. If the proposed sewage system crosses this known site, or the bench below it, where archaeological remains probably are buried, we recommend a testing program prior to modification. The site will be nominated to the National Register of Historic Places.

McQueeney $\# 5$ (4.1 GU 14). This site has been extensively damaged by plowing. However, if project plans include any modification of the locality there is a small area that should be tested to secure more archaeological data. The field bordering this site is apparently the source of the chert used in both sites 41 GU 14 and 41 GU 15. There is a high probability that there is an associated occupation on the bench below the ridge, and it too, should be tested if modification is anticipated. 
McQueeney \#6 (41 GU 15). This is probably a satellite site linked to an occupation site somewhere in the bench area below, an area which was unavailable to the field team. While $41 \mathrm{GU} 15$ is not considered worthy of further action, a survey of the area should be carried out if it appears that it will be modified by the proposed project.

Finally, any future survey work should cover those few areas that could not be examined by the field team due to lack of time or landowner problems. For example, the entire long ridge on the east side of the Guadalupe River should be carefully examined. There is also a small undeveloped area on both sides of the bend in the river just north of this ridge. Two fields west of this long ridge and three fields to the east should be checked. Approximately one-half mile of Youngs Creek above its confluence with the Guadalupe River was not explored.

In conclusion, it can be stated that while much disturbance has already occurred in the area slated for the sewage treatment system, there are still some archaeological sites that survive. Additional survey would undoubtedly reveal other sites. Because so many of the prehistoric resources of the McQueeney area has already been lost, it is imperative that the protection of these resources be carefully considered during the final planning stage of this project. 


\section{REFERENCES CITED}

General Rules of Practice and Procedure

1976 General Rules of Practice and Procedure. 355.01.01.001.016. Texas Antiquities Committee, Office of the State Archeologist. 355.01. $12 \mathrm{pp}$. Austin.

Harper, $V$.

1974 Texas Family Land Heritage Registry. First Edition. Texas Department of Agriculture, Austin.

Hester, T. R. (assembler)

1974 Archaeological and Historical Resources in the San AntonioGuadalupe River Basins: A Preliminary Statement. Center for Archaeological Research. The University of Texas at San Antonio, Regional Studies 1 .

Patterson, J.T.

1936 The Corner-Tang Flint Artifacts of Texas. University of Texas Bulletin 3678.

1937a Boat-Shaped Artifacts of the Gulf Southwest States. University of Texas Bulletin 3732.

1937b Supplementary Notes on the Corner-Tang Artifact. University of Texas Bulletin 3734. 